\title{
Crude protein degradability, fibre and tannin levels of browse forages in an extensive farming system*
}

\author{
G.T. Kamupingene ${ }^{1,3}$, A.L. Abate ${ }^{1}$ and A.E. Kimambo ${ }^{2}$ \\ ${ }^{1}$ Department of Animal Science, University of Namibia, Private Bag 13301, Namibia \\ ${ }^{2}$ Department of Animal Science and Production, Sokoine University of Agriculture \\ P.O. Box 3004, Morogoro, Tanzania
}

\begin{abstract}
Nutrient concentrations and ruminal degradability of the crude protein $(\mathrm{CP})$ of selected browse forages consumed by goats in east-central Namibia were studied. All forages varied significantly $(\mathrm{P}<0.05)$ in the parameters studied. Crude protein (mean $17.9 \pm 0.64 \%$ DM) ranged from 11.6 to $26.2 \%$ in Terminalia sericea and Acacia reficiens leaves, respectively. Total condensed tannins (TCTs) were low and ranged between 0.39 and $4.21 \%$ DM. Neutral detergent fibre (NDF), with a mean value of $41.5 \pm 0.84 \% \mathrm{DM}$, was lowest (30.9\%) and highest (58.3\%) in the parasitic plant Tapinanthus oleifolius growing on Acacia mellifera and Lonchocarpus nelsii leaves, respectively. The same forages had, similarly, the lowest $(22.5 \% \mathrm{DM})$ and highest $(38.7 \% \mathrm{DM})$ acid detergent fibre (ADF) values.

Acacia hebeclada leaves had the least $(6.31 \% \mathrm{CP}$ ) soluble (a) feed protein (mean $9.11 \pm 0.36 \% \mathrm{CP}$ ), while $A$. reficiens had the most $(13.5 \% \mathrm{CP})$ soluble feed protein. The potentially degradable fraction (b) of the feed protein ranged between 72.1 and $83.6 \% \mathrm{CP}$. Leaves from A. hebeclada had the highest rumen undegradable protein (rUDP) content (mean $6.75 \pm 0.23 \%$ DM) of $9.69 \%$, while those of T. sericea had the lowest value $(4.07 \%)$ for the same parameter. Terminalia sericea had also the lowest $(7.31 \% \mathrm{DM})$ effective rumen degradable protein (ERDP), which was highest $(17.8 \% \mathrm{DM})$ in $A$. reficiens leaves. Generally, the most preferred forages had high CP, rUDP and ERDP contents and low tannin levels, while the parasitic plants were low in fibres and, correspondingly, high in total digestible nutrients (TDN). It was concluded that the browse forages in the study area have low tannin levels and the necessary quality to promote goat productivity even under in-door feeding conditions.
\end{abstract}

KEY WORDS: degradability, fibres, forages, protein, tannin

\section{INTRODUCTION}

High levels of tannins and their effects on protein degradability are known to affect animal performance adversely. A poorly degraded protein will result in low quantities

\footnotetext{
${ }^{*}$ Supported by DANIDA through the ENRECA ASLIP Project

${ }^{3}$ Corresponding author: e-mail: gkamupingene@unam.na
} 
of nitrogen absorbed and this would also influence its utilization by the animal. Reports of the effects of protein degradation on animal performance are variable. Baker et al. (1996) and Cunningham et al. (1996) reported milk production in dairy cows to increase when large quantities of rumen undegradable protein (RUP) were fed. In contrast, Ellison et al. (1997) reported a decrease in milk production as the dietary RUP content was increased. These variations are known to be due to nutrient interactions (Jones et al., 2000). Thus, knowledge of the nutrient concentrations of feed resources would be useful in predicting animal performance.

This study was, therefore, aimed at quantifying the nutrient concentrations and evaluating the degradability of $\mathrm{CP}$ of browse forages known to contribute significantly to goat diets in a free-range system of Okondjatu Communal Area (OCA) in east-central Namibia.

\section{MATERIAL AND METHODS}

Through Participatory Rural Appraisal (PRA) methods, the most preferred and less preferred browse species by goats in the study area were determined and their leaves and tender twigs collected for nutrient (CP, NDF and ADF) analysis following standard procedures. Tannins (TCTs) were assayed using the Butanol$\mathrm{HCL}-\mathrm{Fe}^{3+}$ assay, while TDN were calculated using a prediction equation (Moore and Undersander, 2002). The nylon bag procedure was used for determining ruminal degradation kinetics of CP. Rumen undegradable and effective rumen degradable protein (rUDP and ERDP) were then calculated using standard prediction equations (ARC, 1980; AFRC, 1993). An outflow rate of $2 \% \mathrm{~h}^{-1}$ was assumed for a feeding level approximated to maintenance (AFRC, 1993). The variation between forage samples with respect to the studied parameters was analysed statistically (SAS, 2000) and means were separated by Duncan's multiple range test.

\section{RESULTS AND DISCUSSION}

Crude protein, fibre and TCT values are comparable to those reported by Rubanza et al. (2003). The reported average CP (Table 1) content is more than twice the minimum required to effect cellulolysis in ruminants, while the average ERDP content is enough to support growth rates of between 50 to $100 \mathrm{~g} \mathrm{~d}^{-1}$ in goats (McDonald et al., 1995). High ERDP values imply that the growth and multiplication of rumen microbes and subsequent microbial protein synthesis will not be limited by the dietary protein intake if these forages were fed solo to animals. Indeed, Nolte et al. (2003) indicated that forage intake, microbial efficiency and microbial nitrogen flow to the duodenum in Dohne Merino wethers was improved when increased amounts of rumen degradable protein was provided. Further, it can be noted that the rUDP content was about half the amount 
of ERDP, a ratio that conforms to what is required by the animal body. However, the relatively low rUDP values reported would necessitate supplementation with rumen by-pass protein, depending on the intended production function.

Table 1. Crude protein degradation characteristics of browse forages

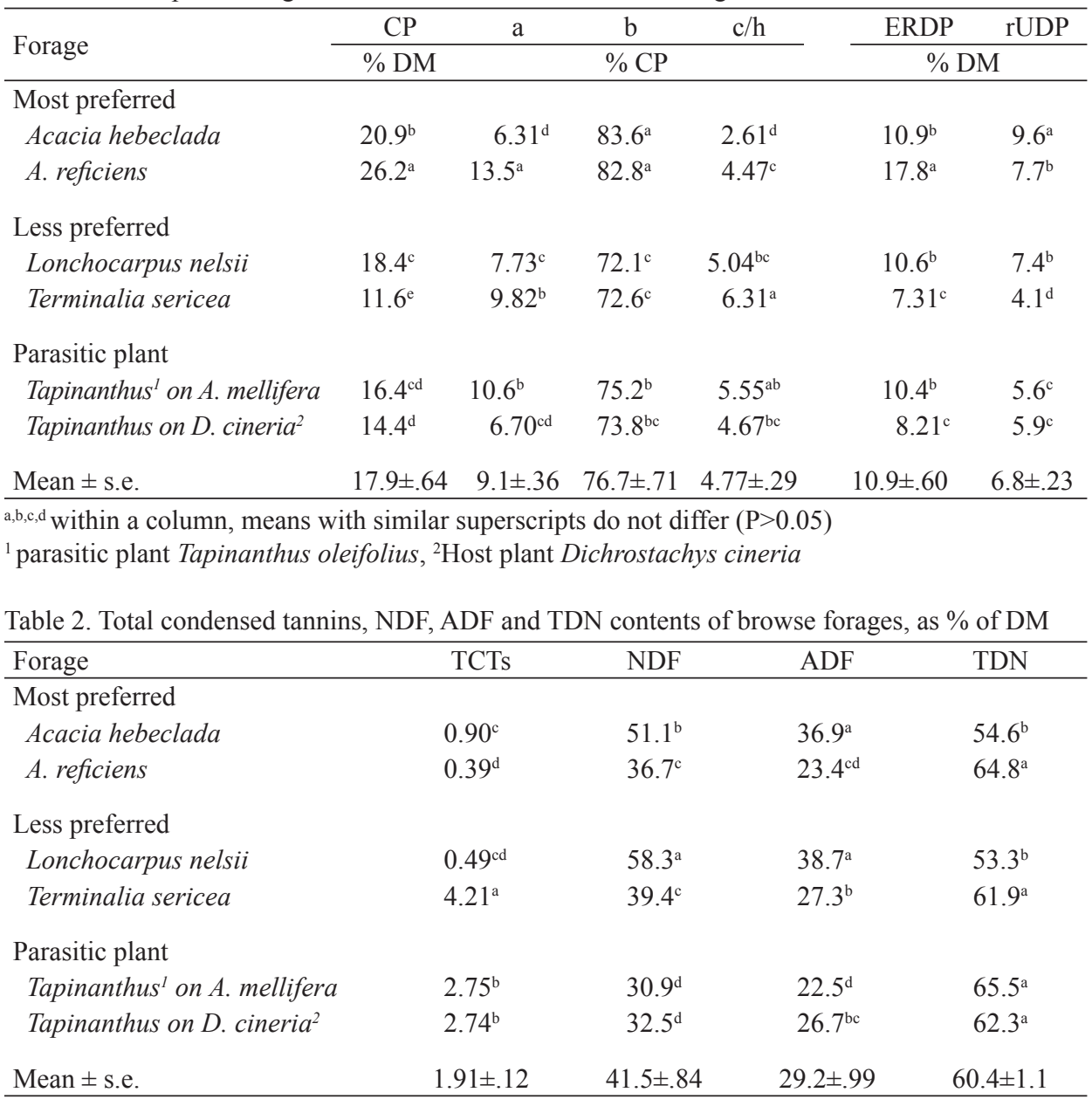

a,b,c,d within a column, means with similar superscripts do not differ $(\mathrm{P}>0.05)$

Fibre contents (Table 2) are within the limits required for a normal rumen environment, while the concentration of TCTs is below the level at which they could lower forage quality. Thus, intake, digestibility and subsequent animal performance would be enhanced if these forages were to be fed to animals. Most of these forages had, also, high TDN values (mean 60\% DM) and this implies that a significant proportion of their energy is available for use by the animal's body. 


\section{CRUDE PROTEIN DEGRADABILITY, FIBRE AND TANNIN IN BROWSE}

\section{CONCLUSIONS}

The study concluded that the browse forages in the study area have low tannin levels and the necessary quality to promote the productivity of goats even under indoor feeding conditions.

\section{REFERENCES}

AFRC, 1993. Energy and Protein Requirements of Ruminants: An Advisory Manual Prepared by the Agricultural and Food Research Council Technical Committee on Responses to Nutrients. CAB International, Wallingford, pp. 159

ARC, 1980. The Nutrient Requirements of Ruminant Livestock. $1^{\text {st }}$ Edition. Technical Review by an Agricultural Research Council Working Party. CAB, Farnham Royal, pp. 351

Baker M.J., Amos H.E., Nelson A., Williams C.C., Froetschel M.A., 1996. Undegraded intake protein: effects on milk production and amino acid utilization by cows fed wheat silage. Can. J. Anim. Sci. 76, 367-376

Cunningham K.D., Cecava M.J., Johnson T.R., Ludden P.A., 1996. Influence of source and amount of dietary protein on milk yield by cows in early lactation. J. Dairy Sci. 79, 620-630

Ellison Henson J., Schingoethe D.J., Maiga H.A., 1997. Lactational evaluation of protein supplements of varying ruminal degradabilities. J. Dairy Sci. 80, 385-392

Jones R.J., Meyer J.H.F., Bechaz M., Stoltz M.A., 2000. An approach to screening potential pasture species for condensed tannin activity. Anim. Feed Sci. Tech. 85, 269-277

McDonald P., Edwards R.A., Greenhalgh J.F.D., Morgan C.A., 1995. Animal Nutrition. $5^{\text {th }}$ Edition. Oliver and Boyd Publishers (UK), pp. 607

Moore J.E., Undersander D.J., 2002. Relative Forage Quality: An alternative to Relative Forage Value and Quality Index. Proceedings of the $13^{\text {th }}$ Annual Florida Ruminant Nutrition Symposium. University of Florida, Gainesville, pp. 16-32

Nolte J. van E., Ferreira A.V., Köster H.H., 2003. Effect of amount of rumen degradable protein on the utilization of wheat straw by Dohne Merino wethers. J. Anim. Sci. 76, 319-326

Rubanza C.D.K., Shem M.N., Otsyina R., Ichinohe T., Fujihara T., 2003. Nutritive evaluation of some browse tree legume foliages native to semi-arid areas in Western Tanzania. Asian-Austr. J. Anim. Sci. 16, 1429-1437

SAS, 2000. Proprietary software release 8.1. Statistical Analysis System Institute, Inc, Cary, North Carolina 